\title{
Fotovoltaik Modüllerin Atık Isılarından Termoelektrik Jeneratör İle Elektrik Üretimi
}

\author{
Ramazan Kayabaş $1^{1 *}$, Metin Kaya ${ }^{2}$ \\ ${ }^{1}$ Kayseri Üniversitesi, Tomarza Mustafa Akıncıoğlu Meslek Yüksekokulu, Kayseri, Türkiye (ORCID: 0000-0001-6195-7445) \\ ${ }^{2}$ Karabük Üniversitesi, Teknoloji Fakültesi, Enerji Sistemleri Mühendisliği Bölümü, Karabük, Türkiye (ORCID: 0000-0001-8524-6250)
}

(Illk Geliş Tarihi 10 Mayıs 2019 ve Kabul Tarihi 1 Haziran 2019)

(DOI: $10.31590 /$ ejosat.562859)

ATIF/REFERENCE: Kayabaşı, R., \& Kaya, M. (2019). Fotovoltaik Modüllerin Atık Isılarından Termoelektrik Jeneratör İle Elektrik Üretimi. Avrupa Bilim ve Teknoloji Dergisi, (16), 310-324.

\section{Öz}

Günümüz teknolojilerinin temelini enerji ve enerji kaynakları oluşturmaktadır. Gelişmiş dünya ülkeleri, enerji kaynaklarına sahip olmak ve enerji teknolojilerini geliştirmek için yarış halindedir. Ayrıca enerjinin verimli kullanılmasını sağlamak bu ülkelere çevresel ve ekonomik olarak avantaj sağlamaktadır. Enerjinin üretimi ve tüketimi esnasında, kaynakların bir kısmı atık 1sı olarak alıcı ortama bırakılmaktadır. Endüstride birçok atık 1sı kaynağı bulunmaktadır. Atık 1Sı kaynaklarının sahip olduğu enerjiyi işe dönüştürmek için araştırma geliştirme faliyetleri artarak devam etmektedir. Atık 1sı kaynaklarından biri fotovoltaik modüllerin yüzeylerinde biriken 1sı enerjisidir. Fotovoltaik modüllerde biriken 1Sı enerjisi modüllerin verimlerini düşürmektedir. Ayrıca yüksek sıcaklık fotovoltaik modüllerin verimli çalışma sürelerini azaltmaktadır. Bu çalışmada fotovoltaik modüllerin yüzeyinde biriken 1sı enerjisi faz değiştiren madde kullanılarak çekilmiştir. Fotovoltaik modüllerden çekilen 1sı enerjisi termoelektrik jenaratörün çalıştırılmasında kullanılmıştır. Fotovoltaik modüllerin yüzey sıcaklığı deneyler esnasında maksimum $90^{\circ} \mathrm{C}$ 'ye ulaşmaktadır. Fotovoltaik modüllere uygulanan isı borusu ve faz değiştiren madde ile modül yüzeyi $30^{\circ} \mathrm{C}$ sıcaklığa kadar soğutulabilmektedir. Sonuç olarak fotovoltaik modülün sıcaklığı sabit tutulmakta ve bu nedenle modül verimleri artmaktadır. Termoelektrik modülün yüzey sıcaklıklarına bağlı olarak termoelektrik jeneratörlerde elektrik üretimi yapılmaktadır. Yüzeyler arasında sıcaklık farkı arttıkça ölçülen gerilim değerleri artış göstermektedir. Termoelektrik modül yüzey sıcaklığ $80^{\circ} \mathrm{C}$ ulaştığında $7.80 \mathrm{~V}$ elektrik enerjisi üretilmektedir. Termoelektrik jeneratörden üretilen güç sıcaklık farkına bağlı olarak $5 \mathrm{~W}$ olarak belirlenmiştir. Termoelektrik jenaratörün yüzeylerinden biri atık 1Sı ile 1stıllırken, diğer yüzeyi tabii ve cebri olarak havayla soğutulmaktadır. Cebri olarak soğutulan termoelektrik jeneratörün yüzeyleri arasında $51^{\circ} \mathrm{C}$ sıcaklık farkı oluşrurken, doğal olarak soğutulan termoelektrik jeneratörün yüzeyleri arasında $26^{\circ} \mathrm{C}$ sıcaklık fark oluşmaktadır. Atık 1sı kaynaklı termoelektrik jeneratör kullanılarak, elektrik enerjisi üretilmektedir. Sistem hibrit olarak çalışı̆̆ı için toplam verim artmaktadır.

Anahtar Kelimeler: Termoelektrik Jeneratör, Fotovoltaik Panel, Faz Değiştiren Madde. Atık Isı Geri Kazanım Sistemi.

\section{Electricity Generation with Thermoelectric Generators From Waste Heat of Photovoltaic Modules}

\begin{abstract}
Energy and energy resources are the basis of today's technologies. Developed countries are competing to have energy resources and develop energy technologies. In addition, ensuring efficient use of energy provides an environmental and economic advantage to these
\end{abstract}

* Sorumlu Yazar: Kyseri Üniversitesi, Tomarza Mustafa Akıncıŏlu Meslek Yüksekokulu, Kayseri, Türkiye, ORCID: 0000-0001-6195-7445, rkayabasi@erciyes.edu.tr 
countries. During the production and consumption of energy, some of the resources are left to the receiving environment as waste heat. There are many waste heat sources in the industry. Research and development activities continue to increase in order to convert the energy of waste heat sources to work. One of the waste heat sources is the heat energy accumulated on the surfaces of photovoltaic modules. Heat energy accumulating in photovoltaic modules reduces the efficiency of modules. In addition, high temperature reduces the efficient operating time of photovoltaic modules. In this study, heat energy accumulated on the surface of photovoltaic modules was absorbed using phase-changing material. The heat energy extracted from photovoltaic modules is used in the operation of the thermoelectric generator. The surface temperature of the photovoltaic modules reaches a maximum of $90^{\circ} \mathrm{C}$ during the experiments. The heat pipe applied to the photovoltaic modules and the phase-changing material can be cooled up to $30^{\circ} \mathrm{C}$. As a result, the temperature of the photovoltaic module is kept constant and therefore the module efficiency increases. Depending on the surface temperatures of the thermoelectric module, electricity production is made in thermoelectric generators. As the temperature difference increases between the surfaces, the measured voltage values increase. The thermoelectric module is produced from $7.80 \mathrm{~V}$ electrical energy when the surface temperature reaches $80^{\circ} \mathrm{C}$. The power generated from the thermoelectric generator is determined as $5 \mathrm{~W}$ depending on the temperature difference. One of the faces of the thermoelectric generator is heated by waste heat while the other surface is cooled by natural and forced air. The temperature difference between the surfaces of the naturally cooled thermoelectric generator consists of $51^{\circ} \mathrm{C}$, while the temperature difference between the surfaces of the naturally cooled thermoelectric generator consists of $26^{\circ} \mathrm{C}$. Electrical energy is produced by using thermoelectric generator from waste heat. Since the system operates as a hybrid, the total efficiency increases.

Keywords: Thermoelectric Generator, Photovoltaic Panel, Phase Change Material, Waste Heat Recovery System.

\section{Giriş}

Enerji kaynaklarını genel olarak fosil kökenli enerji kaynakları, yenilenebilir enerji kaynakları ve nükleer enerji kaynakları olarak sınıflandırmak mümkündür. Fosil kökenli yakıtlar yenilenemez enerji kaynaklarını oluşturmaktadır. Fosil yakıtlar rezervlerine bağlı olarak, gelecekte artan enerji taleplerine cevap veremeyecek durumdadır (Şekil 1). Nükleer enerji kaynaklarının kullanımı için gelişmemiş ülkeler yeterli teknolojik altyapıya sahip bulunmamaktadır. Nükleer enerjinin güvenli olarak işletilmesi için nükleer teknolojilere sahip bulunmak gerekmektedir. Nükleer enerjiyi diğer enerji kaynakları gibi, küçük ölçekli uygulamalarda kullanmak günümüz teknolojileriyle ekonomik ve güvenli değildir. Ayrıca nükleer atıklar nedeniyle çevresel sorunlar oluşturmaktadır. Yenilenebilir enerji kaynakları her geçen gün teknolojilerinin gelişmesi nedeniyle yaygınlaşmaya başlamıştır. Yenilenebilir enerji kaynakları büyük ve küçük ölçekli uygulamalar için elverişli olarak enerji üretimine firsat sunmaktadır. Ayrıca biriken çevre sorunları nedeniyle yenilenebilir enerji kaynaklarına yöneliş artmaktadır. Gelecek yüzyılda yenilenebilir enerji kaynaklarını yöneten ve ileri teknoloji altyapısına sahip olan ülkeler enerjide söz sahibi olacaklardır.

Enerji kaynaklarının verimli kullanılması ve mevcut kullanılan teknolojilerin verimlerinin arttırılmasına yönelik çok sayıda çalışma bulunmaktadır. Enerji kaynaklarının verimli kullanılması ve kullanılan teknolojilerin verimlerinin arttırılması konusundaki çalışmalar ülkemiz tarafından desteklenmektedir. Bu amaçla, ülkemizde olduğu gibi tüm dünyada mevcut enerji kaynaklarından etkin şekilde yararlanılmalıdır. Enerji kaynaklarına uygun dönüşüm teknolojilerinin kullanılmalı ve enerji depolama teknolojilerinin geliştirilmelidir [1].

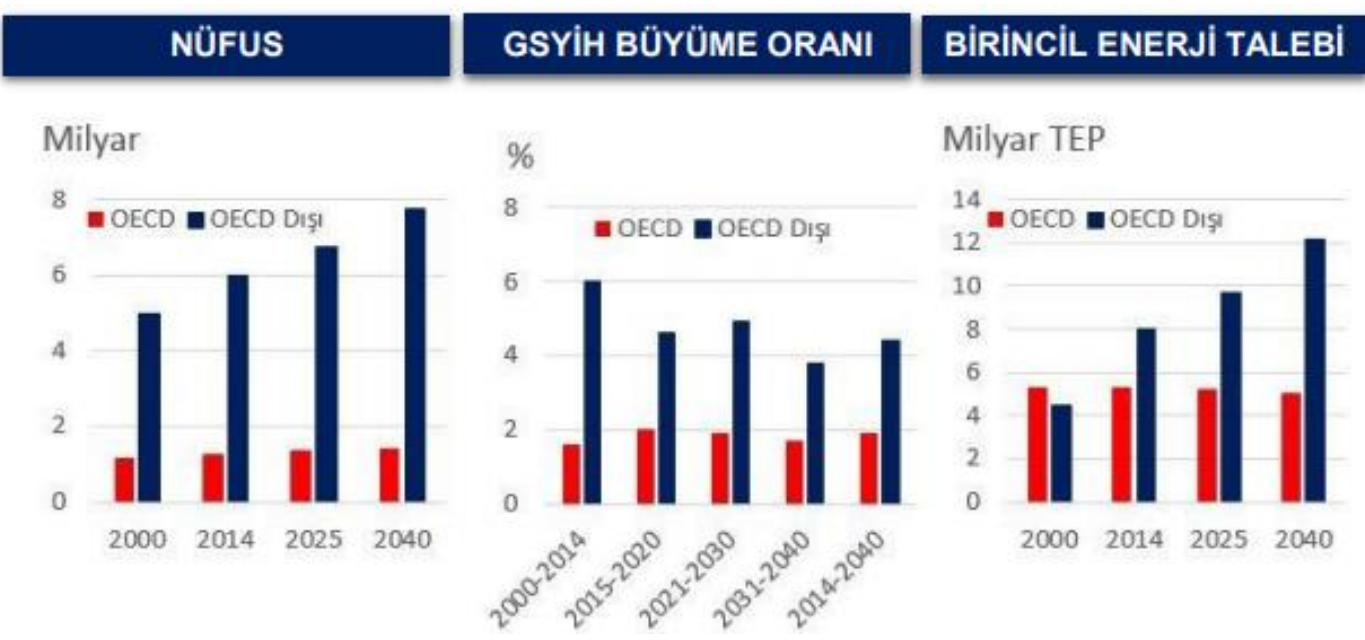

Şekil 1. OECD ve OECD Dışı Ülkelerde Nüfus, GSYİH Büyüme Oranı ve Birincil Enerji Talebi Durum-Senaryoları [2]

OECD ve OECD dışı ülkelerde (Şekil 1) kurgulanan senaryolara göre 2040 yılına kadar fosil yakıtların kullanımı artış görülmektedir. Fosil yakıtların taleplerinde nispeten azalma olmasına rağmen bu yakıtlar önemini korumaya devam etmektedir. Nüfus artışı ve GSYİH büyüme oranına bağlı olarak enerji taleplerinde hızlı bir artış görülmektedir. Ekonomik kalkınma nedeniyle enerji kullanım oranı artış göstermekte, bu durum yıllık enerji tüketimini arttırmaktadır. Küresel enerji talepleri benimsenecek enerji politikalarına bağlı olarak farklılık gösterebilecektir. Küresel enerji talepleri güncel senaryolara göre yıllık \%2.3, 2040 yılında ise \%80 oranında artış beklenilmektedir. Dünyada belirlenen kaynaklara göre toplam petrol rezervleri 1,7 trilyon varil olarak tahmin edilmektedir. Enerji taleplerine bağlı olarak yaklaşık 51 y1llık talepleri karşılayabileceği düşünülmektedir. Doğal gaz rezervi yaklaşık 187 trilyon metreküp olarak belirlenmiştir. Doğal gaz rezervleri küresel üretimi 53 yıl karşılayabilmektedir. Dünya kömür rezervleri 
tüm yakıtlar arasında en yüksek rezerve sahiptir. Küresel üretimi 114 yıl boyunca karşılamayabileceği tahmin edilmektedir. Yenilenebilir enerji kaynaklarının enerji üretimindeki payı yıllara göre artış göstermektedir. 2040 yılında yenilenebilir enerji kaynaklarının enerji üretimindeki payı \%16.1 olacağı beklenilmektedir. Yenilenebilir enerji kaynakları yıllık ortalama \%9.8 büyüme oranı ile en hızlı büyüme oranına sahip kaynaklardır [2].

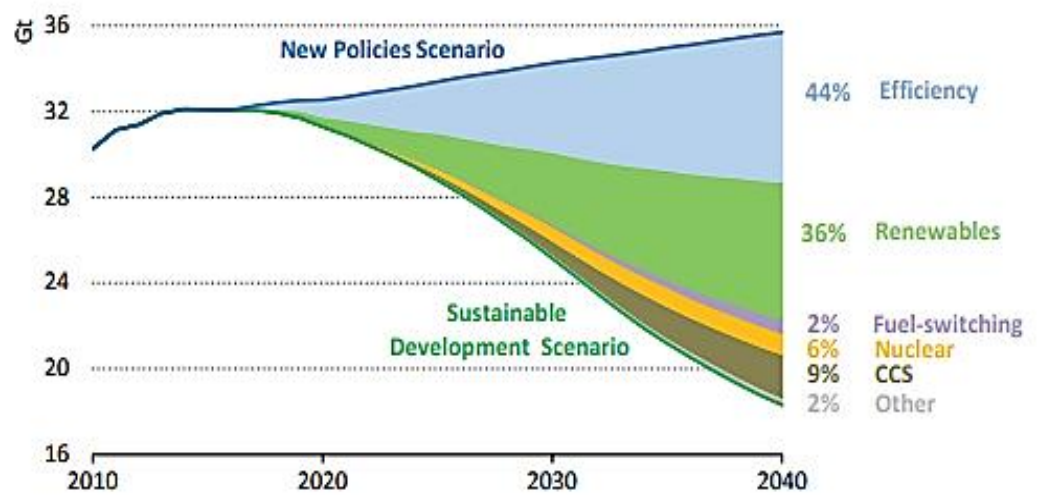

Şekil 2. Dünya Sürdürülebilir Kalkınma Politikaları ve Küresel Karbondioksit Salınımı Azaltma Hedefleri[3]

Sürdürülebilir kalkınma politikaları ve enerji senaryolarında yenilenebilir enerji kaynaklarının kullanımının artacağı (Şekil 2) öngörülmektedir. Kullanılan teknolojilerin gelişimini sağlamak enerji kaynaklarının verimli kullanılması için hayati öneme sahiptir. Enerji kaynaklarının verimli olarak kullanılması ve enerji teknolojilerinin gelişmesi fosil enerji kaynakları dâhil diğer enerji kaynaklarının da verimli kullanılması anlamına gelir. Verimli enerji senaryosunda yöntem ve varsayımlara bakıldığında enerjinin verimli kullanımı ekonomik olarak yarar sağlayacağı gibi çevresel sorunlarla mücadelede büyük katkı sunmaktadır. Enerji kaynaklarının verimli kullanılması çevreye olan karbondioksit $\left(\mathrm{CO}_{2}\right)$ salınımı oranını azaltır. Bu durum hava kalitesini arttırırken yaşanan sağlık sorunlarına engel olur. Mevcut verimlilik hedeflerini gerçekleştirmek, artan enerji talebine cevap vermede yarar sağlayacaktır.

TE modüllerin elektrik enerjisi üretebilmesi için yüzeyler arası sıcaklık farkı oluşturulmalıdır. Sıcaklık farkı oluşturmak için fosil yakıtları kullanmak ekonomik olmamaktadır. \% 3 ile \% 5 verim aralığında çalışan modüller için enerji harcayarak sıcaklık farkı oluşturmak çok defa denenmiş ve çalışılmış bir konudur. Enerji harcayarak yapılan çalışmalarda; enerji harcamadan sıcaklık farkı oluşturulması savunulmuştur. Bu nedenle jeotermal enerji, endüstriyel atık 1sı veya güneş enerjisi kaynak olarak kullanılması sistemin ekonomik olarak çalışabilmesi için önemlidir. Bu nedenle PV panellerrin yüzeyinde biriken atık 1sı kaynak olarak seçilmiştir. PV'lerin çalışma şartları esnasında yüzeylerinde biriken atık ısı ekonomik bir kaynak özelliği taşımaktadır.

$\mathrm{Bu}$ çalışmada fotovoltaik (PV) modüllerin yüzeyinde biriken atık 1sının çekilmesi ve modül verimlerinin arttırılması için panellerde faz değiştiren madde (FDM) kullanılmıştır. Deneysel çalışmada panellerde biriken atık 1sı enerjisi panellerden 1sı borusu ve FDM vasıtasıyla çekilmiştir. Çekilen 1sı enerjisi termoelektrik jeneratörlerde (TEJ) elektrik üretmek için 1sı farkı oluşturmak amacıyla deneysel çalışmada kullanılmıştır. Çalışmada amaç PV panel veriminin düşmesine neden olan 1Sı enerjisi kullanılarak elektrik enerjisi üretilmesidir. Bu durum ayrıca toplam verimin artışına da neden olmaktadır. PV modül sıcaklığı dengelenmesi nedeniyle panel ömürleri ve verimlerinde artış görülmektedir. TEJ ile atık 1sı elektrik enerjisine dönüştürülmüştür. Sistem birlikte çalıştırılarak hibrit bir sistem oluşturulmuştur.

\subsection{Yenilenebilir Enerji Kaynakları}

Yenilenebilir enerji kaynakları, doğanın döngüsü sonucunda var olan ve ömrü bu döngüye bağlı olan enerji kaynaklarıdır. Yenilenebilir enerji kaynaklarından enerji üretimi çevre kirliliğini önleme açısından çok önemlidir. Karbon salınımının düşürülmesi ve küresel ısınmanın azaltılması için, yenilenebilir enerji kullanımının yaygınlaştırılması gerekmektedir. Güneş enerjisi, rüzgâr enerjisi, jeotermal enerji, hidrolik enerjisi, biokütle enerjisi, dalga enerjisi ve hidrojen enerjisi yenilenebilir enerji kaynaklarından sağlanan enerji türleridir. Türkiye konumu ve potansiyelleri gereği, bu enerji kaynaklarına sahip ülkeler arasındadır. Sahip olduğu teknoloji altyapısına bağlı olarak bu kaynakları kullanabilir durumdadır. Türkiye, özellikle güneş, rüzgâr ve jeotermal olmak üzere, yenilenebilir enerji kaynakları için yüksek bir potansiyele sahiptir. Bu nedenle var olan potansiyellerin enerji üretimindeki oranlarının arttırılması gerekmektedir. Türkiye'de 2018 yılı için yenilenebilir enerji kaynaklarından (Tablo 1) enerji üretim değerleri verilmiştir. Yenilenebilir enerji kaynakları kaynağın durumuna göre aylık değişken oranlarda elektrik enerjisi üretimi için kullanılmıştır.

Tablo 1. Türkiye'nin 2018 Yılı Yenilenebilir Enerji Kaynakları Elektrik Üretimi [4] 


\begin{tabular}{|c|c|c|c|c|c|c|c|c|c|c|c|c|}
\hline $\begin{array}{l}\text { Yakit } \\
\text { Türleri }\end{array}$ & Ocak & Şubat & Mart & Nisan & Mayıs & Haziran & Temmuz & Ağustos & Eylül & Ekim & Kasım & Aralık \\
\hline Jeotermal & $1.063,7$ & $1.063,7$ & $1.129,2$ & $1.129,2$ & $1.129,2$ & $1.144,2$ & $1.163,6$ & $1.163,6$ & $1.198,7$ & $1.282,5$ & $1.282,5$ & $1.282,5$ \\
\hline $\begin{array}{l}\text { Hidrolik } \\
\text { Barajlı }\end{array}$ & 19.914 & 19.914 & $19.881,0$ & $19.922,1$ & $20.121,5$ & $20.304,1$ & $20.503,5$ & $20.503,5$ & $20.503,5$ & 20.503 & $20.504,8$ & $20.536,1$ \\
\hline $\begin{array}{l}\text { Hidrolik } \\
\text { Akarsu }\end{array}$ & $7.532,5$ & $7.535,1$ & $7.574,4$ & $7.579,5$ & $7.593,4$ & $7.600,6$ & $7.600,6$ & $7.602,7$ & $7.643,2$ & $7.737,0$ & $7.740,9$ & $7.747,7$ \\
\hline Rüzgâr & $6.507,6$ & $6.523,6$ & $6.561,9$ & $6.615,1$ & $6.617,1$ & $6.620,6$ & $6.641,7$ & $6.685,1$ & $6.760,5$ & $6.825,0$ & $6.886,9$ & $6.942,3$ \\
\hline Güneş & 22,9 & 22,9 & 22,9 & 22,9 & 22,9 & 22,9 & 22,9 & 31,9 & 81,7 & 81,7 & 81,7 & 81,7 \\
\hline $\begin{array}{l}\text { Rüzgâr } \\
\text { (Lisanssız) }\end{array}$ & 40,9 & 46,9 & 46,9 & 49,4 & 50,3 & 50,8 & 50,8 & 57,3 & 57,3 & 58,2 & 62,2 & 63,1 \\
\hline $\begin{array}{l}\text { Hidrolik } \\
\text { (Lisanssız) }\end{array}$ & 7,4 & 7,4 & 7,4 & 7,4 & 7,4 & 7,4 & 7,4 & 7,4 & 7,4 & 7,4 & 7,6 & 7,6 \\
\hline $\begin{array}{l}\text { Güneş } \\
\text { (Lisanssız) }\end{array}$ & $3.455,8$ & $3.919,2$ & $4.567,4$ & $4.605,0$ & $4.680,0$ & $4.703,0$ & $4.721,0$ & $4.761,0$ & $4.768,0$ & $4.842,0$ & $4.920,8$ & $4.981,2$ \\
\hline Toplam & $38.544,8$ & $39.032,8$ & $39.791,1$ & $39.930,6$ & $40.221,8$ & $40.453,6$ & $40.711,5$ & $40.812,5$ & $41.020,3$ & $41.337,3$ & $41.487,4$ & $41.642,2$ \\
\hline
\end{tabular}

Türkiye coğrafi konumu nedeniyle, güneş enerjisi açısından yüksek potansiyele sahip bir ülkedir. Türkiye'nin yıllık güneşlenme süresi 2737 saat ve ortalama güneş enerjisi potansiyeli $1527 \mathrm{kWh} / \mathrm{m}^{2}$-yıl seviyesindedir. Ortalama olarak günlük 7,5 saat güneşlenme süresine sahiptir [5]. Türkiye'nin güney bölgesi güneş 1şınımı açısından diğer bölgelere göre daha yüksek potansiyele sahiptir. Bölgelerine göre farklılık görülmesine rağmen potansiyel açısından ülkemizin tüm bölgelerinin ışınım değerleri; Avrupa birliği ortalamasından yüksek durumdadır. Türkiye Almanya'nın sahip olduğu güneş enerji potansiyelinden daha fazla potansiyele sahipken; kurulu güç bakımından Almanya'nın \%8'i kadardır (Tablo 2).

Tablo 2. Ülkelerin 2017 Yılsonu Yenilenebilir Elektrik Kurulu Güç Kapasitesi (GW) [6]

\begin{tabular}{lccccccc}
\hline Enerji Kaynakları & Çin & ABD & Hindistan & Almanya & Türkiye & Avrupa & Dünya \\
\hline Hidrolik & 313 & 80 & 47 & 5,6 & 27,2 & 127 & 1114 \\
Rüzgar & 188 & 89 & 33 & 56 & 6,8 & 169 & 539 \\
Biyoenerji & 15 & 16,7 & 9,5 & 8 & 0,63 & 40 & 122 \\
Güneş PV & 131 & 51 & 18,3 & 42 & 3,42 & 108 & 442 \\
Güneş Termal & 0 & 1,7 & 0,2 & 0 & 0 & 2,3 & 4,9 \\
Jeotermal & 0 & 3,6 & 0 & 0 & 1,06 & 0,9 & 13,5 \\
\hline Toplam & 647 & 242 & 108 & 111,6 & 39,11 & 447,2 & 2235,4 \\
\hline
\end{tabular}

\subsection{Fotovoltaik Piller}

Fotovoltaik piller, yüzeylerine güneşten gelen 1şınlarını doğrudan elektrik enerjisine dönüştüren yarıiletken maddelerden üretilmiş hücrelerdir. Güneşten gelen fotonları elektriğe dönüştüren bu etkiye fotovoltaik etki denilmektedir. Hücrenin üzerine güneş 1şınımı düştüğünde bir Elektro Motor Kuvvet (EMK) indüklenir. Üretilen elektrik enerjisi bağlantı noktasından sisteme enteğre edilerek kullanılmaktadır (Şekil 3). Güneş hücreleri EVA (Etilen Vinil Asetat) katmanı arasına yerleştirilmiş durumdadır. Çerçeve içerisine yerleştirilen hücreler PV panelleri oluşturmaktadır. PV panellerde kaynak olarak güneş enerjisi kullanıldığı için, bu yapı güneş enerjisinden elektrik üretim yöntemlerinden birini oluşturur. Güneş pilleri modül sayısına ve bağlantı şekline bağlı olarak üretilmesi planlanan güç için fotovoltaik sistemlerde çeşitli ebatlarda imal edilmektedir. İmal edilen güneş pili, sistem elemanlarına uyumlu tasarlanmış olan fotovoltaik sisteme bağlantısı yapılarak kullanıma hazır hale getirilmelidir. 


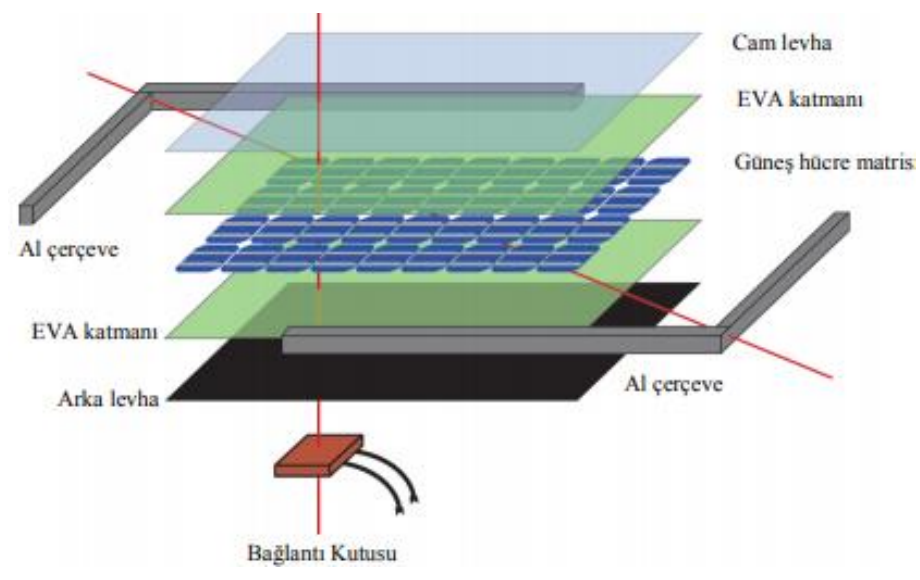

Şekil 3. Güneş Pilinin Çalışma Prensibi [7]

Laboratuvar şartlarında testleri yapılan PV panellerin verimleri yüksek olsa da kullanım şartlarına bağlı olarak gerçek uygulamalarda verimleri düşük çıkmaktadır. PV pillerin verimleri fotovoltaik pilin üretildiği hammaddeye, yapısına ve ölçüm şartlarına göre değişmekle birlikte; verimi \%5 ile \%35 arasında değişmektedir. Fotovoltaik modüllerin verimleri büyük oranda çalışma sıcaklığına bağlıdır. Aktif soğutma sistemi kullanılan modüllerin verimi \%9 dolaylarında artmaktadır. Kombine solar Fotovoltaik (PV) ve Termoelektrik Jeneratör (TEJ) sisteminin PV arkasında doğrudan uygulanmasıyla birlikte daha büyük güçlerde elektrik üretimi yapılabilmektedir. PV modülün verimi; PV malzeme bileşimine, güneş 1şınım şiddetine, ortam sıcaklığı ve modül sıcaklığına bağlıdır $[8,9,10]$.

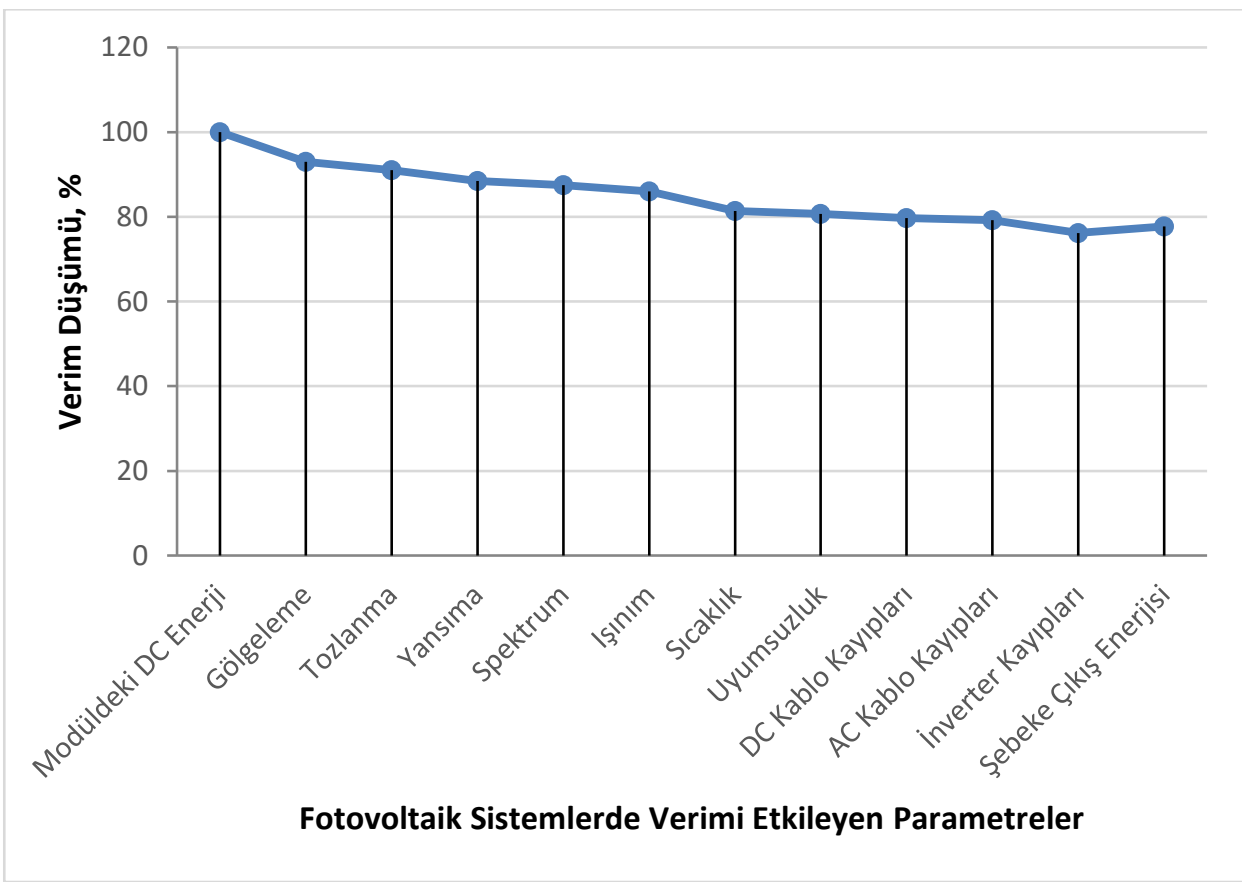

Şekil 4. PV Sistemlerde Verimi Etkileyen Parametreler ve Yüzde Değerleri [11]

Atık 1Sı kaynaklarından biri fotovoltaik modüllerin yüzeyinde biriken 1sı enerjisidir. Bu 1sı enerjisi modüllerin verimlerini düşürmekle birlikte ömürlerini de azaltmaktadır. Modül yüzeyinden FDM ve 1sı borusu 1sı çekmesiyle birlikte sıcaklık artışı nedeniyle meydana gelen olumsuz etkiler azalmaktadır. Modüllerde sıcaklığın istikrarlı hale gelmesi sonucunda sıcaklığın etkisinden kaynaklanan verim düşümü yaşanmaz. Çekilen atık 1sı Termoelektrik Jeneratör (TEJ) vasıtasıyla tekrar elektrik enerjisine dönüştürülmektedir.

PV sistemlerde verim düşüşüne neden olan etkiler sadece sıcaklık nedeniyle değildir. Sıcaklık artışı haricinde; gölgelenme kayıpları, tozlanma sonucunda oluşan kayıplar, kablo kayıpları, inverter kayıpları gibi (Şekil 4)’te verilen birçok kayıp bulunmaktadır. Bu kayıplar verim düşümüne neden olmakta ve sistemin toplam verimini olumsuz etkilemektedirler. 


\subsection{Faz Değiştiren Madde}

Isı geçişi cisimler arasında sıcaklık farkı nedeniyle meydana gelir. Yüksek sıcaklığa sahip cisimden düşük sıcaklığa sahip cisme doğru sıcaklık değerleri eşit oluncaya kadar 1S1 geçişi devam eder. Isı enerji bir maddeyi oluşturan atom veya moleküllerin atomik veya moleküler düzeydeki kinetik ve potansiyel enerjilerinin toplamıdır. Termal enerji depolama yöntemleri ısıl yöntem ve kimyasal yöntem olmak üzere ikiye ayrılır. Kullanılan 1sıl yöntemler; duyulur 1sı ve gizli 1sının depolanması şeklinde yapılmaktadır. Kimyasal yöntemler tepkime 1sıs1, kimyasal 1S1 pompası ve termokimyasal 1sı pompasından oluşur. Isı depolama yöntemleri tercih edilirken çevreci olması önemli olmakla birlikte ekonomik olması da önemlidir. Ekonomik olmayan ısı depolama yöntemleri kullanımı zamanla uygulama alanı bulamamaktadır. Çevreye olumsuz etkileri nedeniyle kullanımı yasaklanan yöntemlerde literatürde yöntemler olarak bulunmaktadır.

FDM seçimi yapılırken faz değiştiren maddenin tasarlanan sistemin yapısına uygun olmasına ve faz değiştirme sıcaklığı sistemin çalışma sıcaklığına uyumlu olmasına dikkat edilmelidir. Ayrıca FDM'nin 1sı depolama kapasitesi sistemdeki ısıl yükü karşılayabilmelidir. Birim hacimde inorganik maddeler organik maddelere kıyasla iki kat fazla depolama kapasitesine sahiptirler $[13,14]$.

FDM'lerin faz değitirme süreleri, 1sı tutma kapasiteleri ve 1sı transferi katsayıları çok önemlidir. Bu konularda son yıllarda çok sayıda çalışma yapılmıştır. Faz değişim sürecinin hızlandırılması için 1sı değiştiricisi tasarımı yapılmalıdır. FDM'de 1Sı transferini artırmak için en etkili yol kanatçık kullanımıdır. Kanatçıklı yapı basit olması, kolay temini ve düşük maliyeti nedeniyle tercih edilmektedir [18].

Faz Değiştiren Maddeler (FDM) faz değişimi esnasında termal enerjiyi gizli ısı şeklinde depolayan veya geri veren maddelerdir. FDM'ler faz değiştirme sıcaklığından yüksek değerde bir sicaklıkta 1sıya maruz bırakıldığında materyalin iç enerjilerinde önemli oranda bir değişme olur (Tablo 2). Bu durum materyalin faz değiştirmesine neden olur. Faz değiştirme sınırında materyalin sıcaklığı sabit kalırken; depolama materyalinin faz değiştirmesi ile ortaya çıkan gizli 1Sı depolanabilir [12]. FDM'ler duyulur ve gizli ısı depolama kapasitesi yüksek olan materyaller kullanılarak üretilir. Yapılan çalışmada termal enerji depolamak için Kalsiyum Klorür Hekzahidrat kullanılmıştır. Kimyasal formülü $\mathrm{CACI}_{2} * 6 \mathrm{H}_{2} \mathrm{O}$ olan FDM'nin erime sıcaklığg $29,7^{\circ} \mathrm{C}$, erime $1 \mathrm{~s} 1 \mathrm{~s} 1171 \mathrm{kj} / \mathrm{kg}$ 'dır.

Tablo 2: FDM Türleri ve Özellikleri [12]

\begin{tabular}{lccc}
\hline FDM & Moleküler Formül & Erime Noktası $\left({ }^{\circ} \mathrm{C}\right)$ & Erime Isıs $(\mathrm{kj} / \mathrm{kg})$ \\
\hline Kalsiyum Klorür Hekzahidrat & $\mathrm{CACI}_{2} * 6 \mathrm{H}_{2} \mathrm{O}$ & 29,7 & 171 \\
\hline Oktadekan & $\mathrm{CH}_{3}\left(\mathrm{CH}_{2}\right)_{16} \mathrm{CH}_{3}$ & 24,4 & 244 \\
\hline Potasyum Florür Tetrahidrat & $\mathrm{KF} .4 \mathrm{H}_{2} \mathrm{O}$ & 19 & 231 \\
\hline
\end{tabular}

Sistemde kullanılması düşünülen FDM sistem güvenliğini olumsuz olarak etkilememeldir. FDM'ler inorganik ve organik olmak üzere ikiye ayrılırlar (Şekil 5). İnorganik ve Organik FDM'ler tuz hidratları ve parafinler gibi alt kategorilere ayrılmaktadır. İnorganik ve organik FDM'ler 1sı depolama kapasiteleri, faz değitirme sıcaklıkları, faz dönüşüm sayıları, 1sıl iletkenlikleri, kolay temin edilebilirlikleri ve ekonomiklik durumları nedeniyle birçok avantaj ve dezavantaja sahiptirler. Kullanılacak olan FDM sahip olduğu özelliklere göre seçilerek enerji depolamak amacıyla kullanılmaktadır.

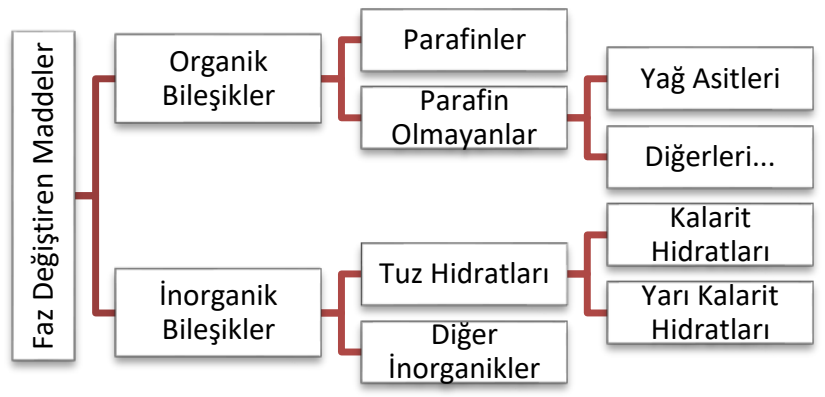

Şekil 5: Faz değiştiren materyallerin sınıflandırılması [15]

FDM ile ısı aktarımı etkin olarak yapılabilmesi için FDM türüne göre uygun kapsülleme uygulamaları bulunmaktadır [16]. FDM'lerin kapsüllenmesi için nano, mikro ve makro kapsülleme yöntemleri kullanılabilmektedir [17]. Isı depolama uygulamaları ile ihtiyaç halinde depolanan ısı enerjisi çekilerek kullanılabilir. Termal enerji depolama sistemlerinin amacı, enerjinin kullanılmayan kısmının veya ihtiyaç fazlasının depolanmasını ve ihtiyaç duyulduğunda bu enerjinin kullanılmasını sağlamaktır. Böylelikle birincil kaynaklardan enerji tüketimi azaltılması mümkündür. Ayrıca 1sı kontrolünün sağlanmasıyla depolanan enerji sayesinde, anlık değişimlerin yaşanması engellenebilmektedir. 


\subsection{Termoelektrik Jeneratörler}

Termoelektrik Modül'ler (TEM) üretiminde iki farklı türden yarı iletken malzeme birbiriyle birleştirilir. Yarı iletkenler ile oluşturulmuş devre üzerinden elektrik akımı geçirilmesiyle sıcaklık farkı meydana gelir. Uçlara uygulanan doğru akımın yönüne göre yüzeylerden biri 1sınırken diğer yüzey soğur. Uygulanan akım sonucunda yariiletkende sıcaklık farkı oluşmasına neden olan etkiye Peltier etkisi denilmiştir. Yarı iletken malzemelerin bağlantı noktaları farklı sıcaklıklara maruz kalırsa Seebeck etkisi ortaya çıkar. Farklı iki yarı iletken uç noktalarından birleştirilip temas noktaları farklı sıcaklıklarda tutulursa; (Şeki 6) elektronlar sıcak uçtan soğuk uca doğru hareket eder ve devre üzerinde EMK indüklenir. TEM bir araya getirilerek Termoelektrik Jeneratörleri (TEJ) oluşturulmaktadır. TEM'ler yüzeyleri arasında sıcaklık farkı oluşturulduğunda doğru akım üreten elemanlardır. TEM'ler yapılarında hareketli parçaları barındırmaması nedeniyle yapıları basittir ve bu nedenle ömürleri uzundur. TEM'ler ısıtma ve soğutma uygulamalarında kullanılabidiği gibi elektrik üretmek için jeneratör olarak kullanılabilmektedir.
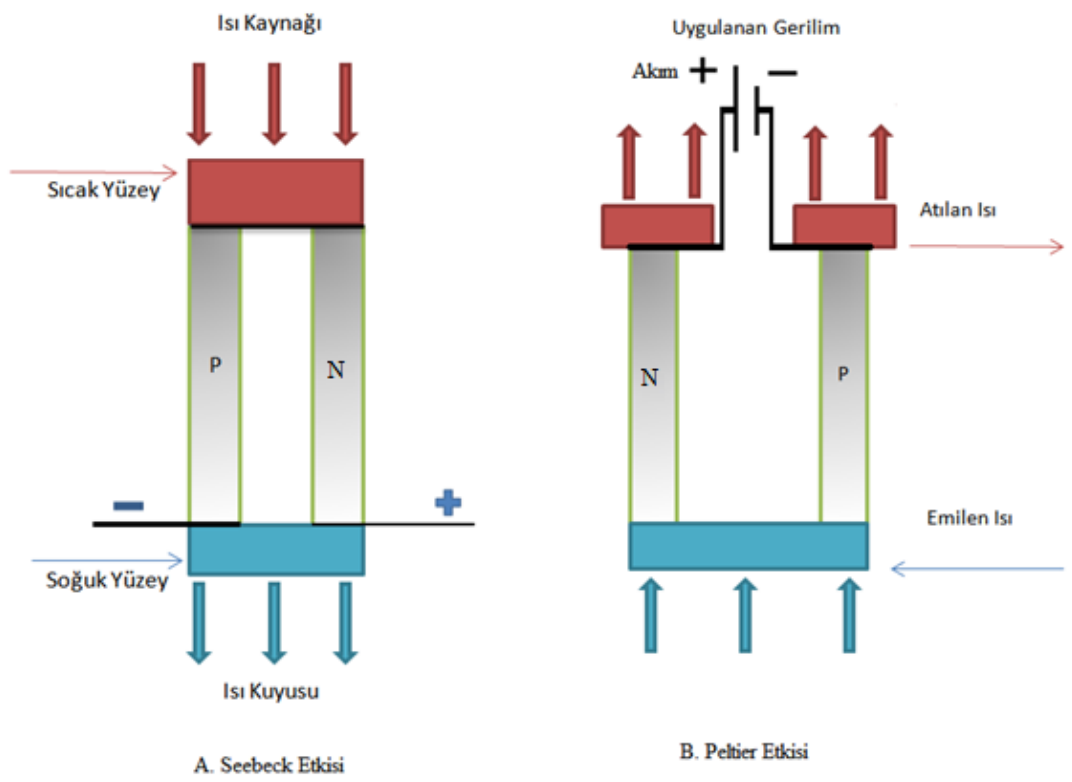

Şekil 6: Seebeck, Peltier, TE Bileşenleri [19]

TEJ'lerin temiz ve gürültüsüz özellikleri birçok zemin uygulamalarında bir elektrik güç kaynağı olarak kabul edilmiştir. Ayrıca (PV/TEJ) sistemi üzerinde güç dönüşüm verimliliğini geliştirmek için yapılan çalışmalardır. Bu sistemlerde bir birleşik termodinamik model sunulmakta, bir uzay ortamında melez PV/TEJ sisteminin çalıştırılması amaçlanmaktadır. Ayrıca, çok objektif NSGA-II genetik algoritma hem optimum çıkış gücü açısından hem de kütle bakımından TEJ tasarımı optimize etmek için kullanılmıştır. Simülasyon sonuçları optimize PV/TEJ sisteminin daha yüksek verime sahip olduğunu göstermiştir [20].

Araçların egzozuna veya soba yüzeyi borusuna bağlı TEJ atık 1sı geri kazanım sistemleri enerji üretimi için tasarlanmıştır. Modül yüzeyleri için sıcaklık farkı oluşturulmuş ve sıcaklık farkından yararlanılarak termoelektrik jeneratörlerin yapısı ve performansı incelenmiştir. Sistemde soğutma amacıyla kullanılan havanın, suyun debisi değiştirilip diğer parametrelerin ölçümü deneysel olarak incelenmiştir. Su debisindeki artı ve eksi değişimlerin elektrik üretim değerlerini pozitif ve negatif yönde değiştirdiği gözlemlenmiştir. TEJ teknolojilerinin sistem verimi düşük olmasına rağmen yüzeyler arası sıcaklık farkının arttırılması ve soğutulan yüzeyden 1sı çekiminin yükseltilmesi ile birlikte verim artışı sağlanabileceği savunulmuştur [21,22].

PV/T/FDM sistemini açık hava şartlarında karakterize edilerek; sistemde isınan su 1sı depolamak ve elektrik üretmek için kullanılmıştır. Sistem tasarımında bir PV modül, bir termal kolektör ile birleştirilmiştir. Böylece 1sı, bir akışkan (su) vasıtasıyla FDM'ye gömülü bir 1Sı eşanjöründen geçirilmiştir. Su ile elde edilen sıcaklığın FDM'si olmayan bir PV/T sistemine kıyasla yaklaşık olarak $5.5^{\circ} \mathrm{C}$ daha yüksek olduğu saptanmıştır. FDM'ler PV/T sisteminde, 1sı depolamanın etkili bir aracı olarak görülmektedir [23].

Farklı iki yarı iletken malzemenin temas noktaları farklı sıcaklıklarda tutulmasıyla elektrik gerilimi oluştuğu görülür. Bu gerilime "Seebeck voltajı" denir (Şekil 6). P tipi yarıiletken malzeme kullanıldığında $\alpha$ değeri ise pozitif olurken N tipi yarıiletken malzeme kullanıldığında $\alpha$ değeri negatif olmaktadır. Devreden ölçülen gerilim, malzemelerin yüzeyleri arasındaki sıcaklık farkı ile doğru orantılıdır. Soğuk (1s1 çekilen) yüzey sıcaklığı Tc, sıcak (1s1 verilen) yüzey $T_{H}$ sıcaklıkları ile sicaklık farkı oluşturulur. Oluşturulan sıcaklık farkı ve iç direnç değerleri $\mathrm{P}_{\max }$ değerlerini belirlemektedir. Maksimum güç çıkışı 
sağlayabilmek için $\left(\mathrm{R}_{\mathrm{L}}=\mathrm{R}\right)$ olmalıdır. Yüzeyler arası sıcaklık farkı $T_{H}-T_{C}=\Delta T$ olduğunda gerilim $\left(\mathrm{V}_{\max }=\mathrm{V}_{R}\right)$ olur. Maksimum verimlilik $\eta_{\max }$ hesaplanır. $\alpha$ ' değerini; devreyi oluşturan malzemelerin özellikleri etkilemektedir.

TEJ için kalite faktörü (Z) tanımlaması yapılır.

$$
Z=\alpha^{2} / R_{k_{t h}}
$$

TEJ elektrik akımı (A) aşă̆ıdaki akım denklemi kullanılarak hesaplanır.

$$
\mathrm{I}=\alpha \Delta \mathrm{T} /[(1+\mathrm{m}) \mathrm{R}]
$$

TEJ'ün elektrik direnci (R), Seebeck sabiti $(\alpha)$ ve RL Yükün elektrik direnci $(\Omega)$ aşağıdaki gibidir. TEJ'in verimliliği yük değeri etkilemekte ve yüke bağlı olarak değişmektedir. Yük direnci için $R_{L}=m R$ varsayılır, $m$ yük direncinin TEJ iç dirence oranıdır.

$$
\begin{gathered}
\alpha=2 V_{\text {max }} / \Delta T \\
R=R_{L}=V_{\text {max }}^{2} / P_{\text {max }}
\end{gathered}
$$

TEJ verimliliğini ve elektrik güç çıkışının hesaplamak için sıcak yüzeye uygulanan termal güç girişi bilinmelidir. TEJ yüzey sıcaklığı $\mathrm{Tc}$, sıcak (1sı verilen) yüzey $\mathrm{T}_{\mathrm{H}}$ sıcaklıkları verim için kullanılabilmektedir.

$$
\mathrm{n}=\mathrm{I}^{2} \mathrm{R}_{\mathrm{L}} / \mathrm{Q}_{\mathrm{H}}
$$

Yük karşılaştırmasında, yük ve iç direnç arasındaki oran $\mathrm{m}_{\text {opt }}$ denklemi ile hesapanır.

$$
m_{\text {opt }}=1+Z_{\text {ave }} 0.5
$$

TEJ maksimum verimliliğinde Burada $\mathrm{m}_{\mathrm{Opt}}$ değeri $\mathrm{m}$ direnç oranının değeridir. Maksimum güç üretimi esnasında verim $\eta_{\max }$ olur. Bu durumda akım değeri aşağıdaki şekilde bulunur.

$$
I_{\max }=\alpha \Delta T / 2 R
$$

TEJ'in termal iletkenliği eşitlik 8'den elde edilebilir.

$$
\kappa_{t h}=\alpha^{2} / R Z
$$

Meydana gelen Seebeck etkisi metallerde termokupl (1s1 sensörü) gibi kullanıllrken yariletkenlerde jeneratör gibi kullanılır. TE modüllerin elektrik üretimi için gerekli sıcaklık değerleri; modülün dinamik, 1sıl ve elektriksel özelliklerine bağlıdır. Çalışan modülün çektiği akımı, uçlarında düşen gerilimi herhangi bir yüzeyindeki sıcaklığının ölçülmesi ile hesaplanabilmektedir [24].

\section{Materyal ve Metot}

\subsection{Sistemin Kurulumu}

Bu çalışmada PV panellerin kullanım şartları esnasında panellerin yapısında biriken atık 1Sı FDM kullanılarak çekilmiştir. Çekilen atık 1sı TEJ'lerin çalıştırılmasında kullanılmıştır. Çalışmada kullanılan 10W iki adet monokristal ve iki adet polikristal panel kullanılmıştır. Panel yüzeyinde 1sı depolama malzemesi olarak Kalsiyum Klorür Hekzahidrat kullanılmıştır. Panel arka yüzeyine 1sı borusu ve FDM kaplama yapılarak panel yüzeyinde ısı birikmesi sonucunda sıcaklık yükselmesi engellenmiştir.

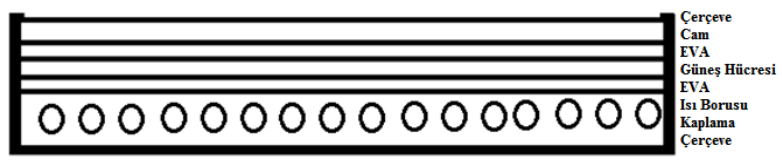

Şekil 7: PV/T Panel

Monokristal panelllerden biri ve polikristal panellerden biri, 1sı borusu montajı yapılarak kullanma hazır hale getirilmiştir (Şekil 7). Isı borusu malzemesi olarak bakır boru kullanılmışır. Isı borusu panel çıkışında dolaşım pompasına eklenerek TEJ devresine bağlanmıştır. 


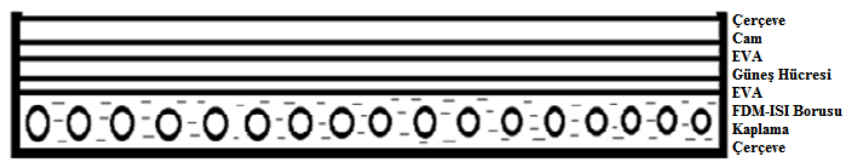

Şekil 8: PV/T/FDM Panel

Monokristal panellerden biri ve polikristal panellerden biri, 1sı borusu montajı yapılarak kullanma hazır hale getirilmiştir (Şekil 8). Isı borusu malzemesi olarak bakır boru kullanılmıştır. Isı borusu panel çıkışında dolaşım pompasına eklenerek TEJ devresine bağlanmıştır. Isı borusu çevresi ithal olarak alınan faz değişim sıcaklığı 29,7 ${ }^{\circ} \mathrm{C}$ olan FDM (Kalsiyum Klorür Hekzahidrat) ile kaplanarak panel yüzeyine sabitlenmiştir. Kullanılan FDM sayesinde panellerin anlık sıcaklık değişimi engellenmiştir. Gün içinde $80^{\circ} \mathrm{C}$ sıcaklık seviyesine paneller çıkarken geceleri ise ani sıcaklık düşümü yaşanmaktadır. FDM'ler sayesinde sıcaklık değişiminde denge sağlanarak verim düşümü engellenmiş, panel ömürleri arttırılmıştır.
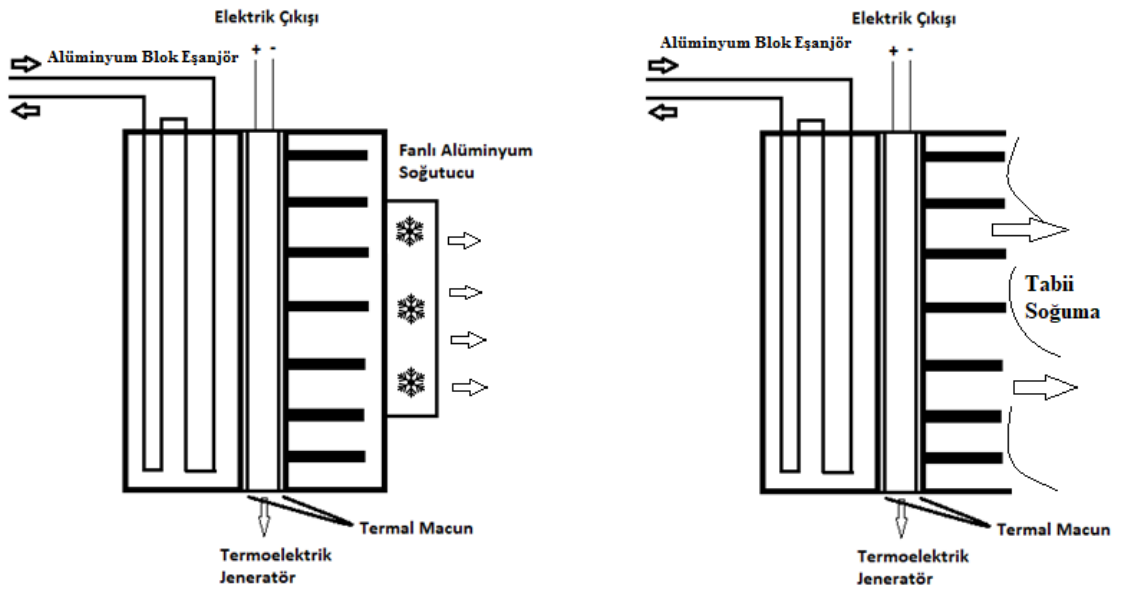

Şekil 9: Atmosferik (TEJ 1) ve Cebri (TEJ2) Soğutuculu Termoelektrik Jeneratör

TEJ içinde, 1sıl enerjiyi elektrik enerjisine dönüştüren TES/TE marka modül kullanılmıştır. Isı değiştirici olarak (841x122x12) mm ölçülerinde alüminyum su soğutma blokları kullanılmıştır. FDM içine yerleştirilmiş bakır 1sı boruları panel yüzeyinde ve FDM içinde biriken atık 1sıyı emerek içinde sirküle edilen suya aktarmaktadır. Bakır boru içinde sirküle olan akışkan sıcaklığı yükselerek izoleli borular içinden TEJ'e gelmektedir. Bu akışkan TEJ'ün 1sıtılması gereken yüzeyin sıcaklığını yükseltmek için kullanılmaktadır. TEJ modülün bir yüzeyi bu sayede yüksek sıcaklığa ulaşmaktadır. TE modülün ikinci yüzeyi için ise 1sı değiştiricinin yüzeyine alüminyum kanatlı bloklar yerleştirilmiştir (Şekil 9).

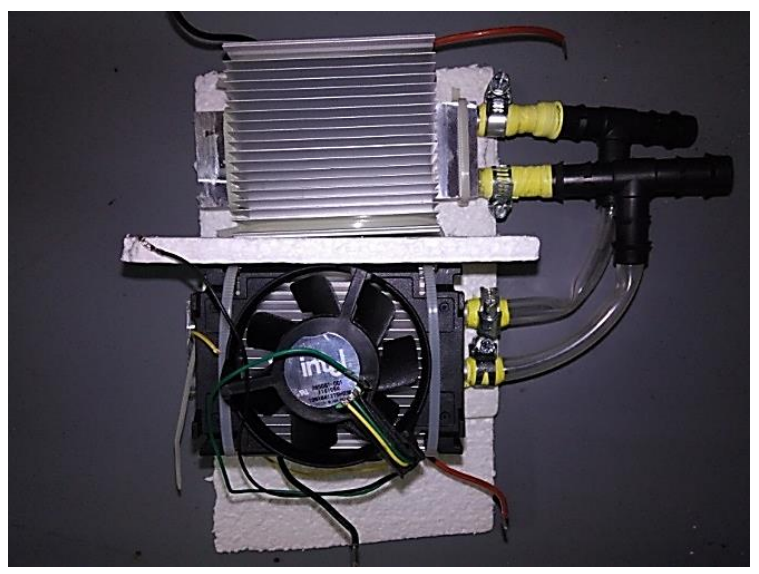

Şekil 10. Termoelektrik Jeneratör Düzeneği

Alüminyum kanatlı blokların birincisinde tabii (atmosferik) soğuma uygulaması yapılmıştır (Şekil 10). Böylelikle fan kullanımından kaynaklı enerji tüketimi bulunmamaktadır. Alüminyum kanatlı blokların diğerinde ise cebri olarak 12V DC fan ile cebri olarak soğuma gerçekleştirilmiştir. Böylelikle TE modülün elektrik üretmesi için gerekli olan sıcaklık farkı oluşturulmuştur. Yüzeyden geçirilen hava tabii ve cebri yol ile iki farklı uygulama yapılmıştır. 


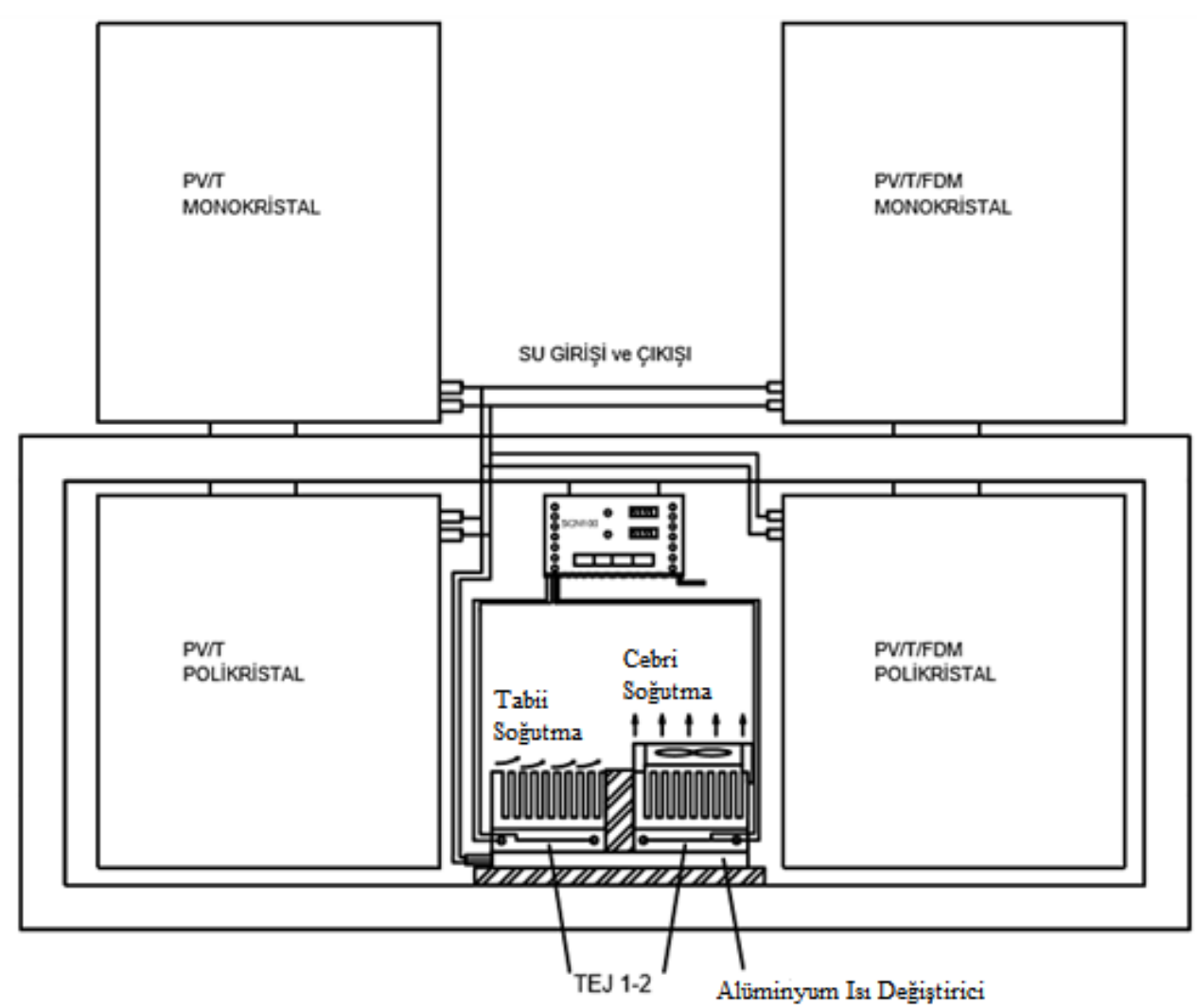

Şekil 11: PV/T ve PV/T(FDM) Sistem Şeması

Deneylerde ölçüm noktalarında sıcaklıkların alınabilmesi için K tipi termokupllar kullanılmıştır. K tipi termokupllar SCN 100 cihazında buzlu su ile $\left(0^{\circ} \mathrm{C}\right)$ kalibrasyonu yapılarak ölçümlere hazırlanmıştır. SCN 100 yirmi kanal ölçüm cihazı kullanılarak ölçümler bilgisayar ortamına aktarılmıştır. Ortam sıcaklığı, su giriş sıcaklığ1, sıcak su çıkış sıcaklığı, soğuk su giriş sıcaklığı, soğuk su çıkış sıcaklığı, kaydedilmiştir. Cebri ve atmosferik olarak soğutulan yüzeylerin sıcaklıkları takip edilmiştir. Sistemde kullanılan suyun sıcak farkı değerlerine bağlı olarak gerilim ve akım değerlerinde değişimler gözlemlenmiştir. Isı değiştirici, direnç devresi, aydınlatma ve şarj devreleri bir kabin içerisine yerleştirilmiş olup; meteorolojik koşullara ve darbelere karşı korunmuştur (Şekil 11).

Deneyler yapılırken PV/T ve PV/T/FDM kullanılan monokristal ve polikristal panellerin çalışma şartlarında yüzeyinde biriken atık ısının çekilebilmesi için sisteme eklenen cebri su dolaşım sistemi çalıştırılmaktadır. Sirkülasyon pompası sistemden aldığı enerji ile sistemde kullanılan suyu cebri olarak dolaştırmaktadır. Sistemde akışkan olarak kullanılan su panellerden 1sıyı emerek TEJ'in yüzeyine 1Sı vermek için kullanılmaktadır (Şekil 12). Sistemde 4 adet monokristal panel ve 4 adet polikristal panel bulunmaktadır. Monokristal panelden biri ve polikristal panellerden biri referans panel olarak konulmuştur. Sistemde iki adet yedek panel yer almakta bu nedenle toplam 8 panel bulunmaktadir.

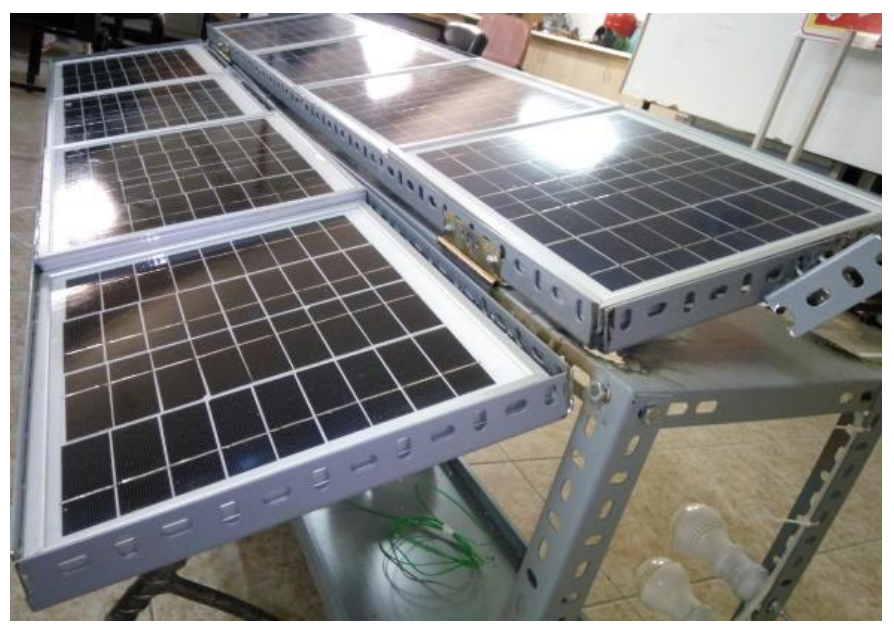

Şekil 12: Deney Düzeneği

\subsubsection{Sistemin Çalışması}

PV paneller çalışma koşullarında güneş ışınlarına maruz bırakıldığında elektrik enerjisi üretmeye başlar. PV sistemin elektrik üretmesi esnasında sistemde istenilmeyen olaylarda yaşanmaya başlamaktadır. PV sistemin sıcaklığı yükselmekte ve sıcaklığa bağlı 
verim düşümü yaşanmaktadır. Tasarlanan sistemde 1Sı borusu ve FDM panel sıcaklığının ani yükselişini engellemektedir. Panel sıcaklığı 1sı borulu sistemde su tarafından emilerek azaltılmaktadır. Sistemden sağlanan sıcak akışkan sirkilasyon pompası vasıtasıyla TEJ devresine yönlendirilmektedir. FDM kulanılan panellerde ise 1sı emilimi FDM tarafından yapılmaktadır. FDM'ye 1Sı geçişinin başlamasıyla birlikte maddenin sıcaklığı yükselmeye başlamaktadır. Sıcaklığı yükselen FDM faz değişimine uğrayarak $29^{\circ} \mathrm{C}$ sıcaklıkta sıvı hale dönüşmektedir. Sistem sıcaklığı artmaya devam ettiğinde FDM sıcaklığı sıvı halde yükselmeye devam etmektedir. Sıcaklığı yükselen FDM' den cebri olarak ısı emilimi sistemde kullanılan su tarafindan yapılmaktadır. Su tarafından çekilen 1sı TEJ sistemine yönelerek enerji üretmek amacıyla kullanılmaktadır.

TEJ sistemine gelen sıcak akışkan jeneratörün bir yüzeyini 1sıtmak için 1sı eşanjörünün içerisinden geçirilmektedir. Isı ejanjörü TEJ'e yüzeyleri arasına termal macun sürülerek sabitlenmiştir. TEJ için gerekli olan 1sı kaynağı, 1sı değiştirici vasıtasıyla sağlanmış bulunmaktadır. TEJ' ün elektrik üretebilmesi için soğuk yüzey tabii ve cebri olarak iki adet alüminyum kanatlı 1sı değiştirici ile sağlanmıştır. Cebri ısı değiştiriciler TEJ'in soğuk yüzeyini sabit sıcaklıkta tutması için sistemle birlikte aktif olarak çalışmaktadır. Böylelikle yüzeyleri arasında sıcaklık farkı oluşan TEJ uçlarında elektrik akımı oluşmaya başlamaktadır. Sıcaklık farkına bağlı olarak sistemin çıkış gerilimi değişmektedir. Sistemden sağlanan güç akü sisteminde depolanmakta ve iki adet doğru akım lambası tarafından kullanılmaktadır. Sistemde TEJ giriş ve çıkış suyu sıcaklıkları akım, gerilim ve güç değerleri ölçülmüştür. Anlık değişimler 0.5 saniye aralıklar ile kaydedilmiştir.

\section{Sonuçlar ve Tartışma}

$\mathrm{PV} / \mathrm{T}$ ve PV/T-FDM kullanılan panellerde panel sıcakları PV panellere göre düşüktür. PV panellerde panel sıcaklığı gün içerisinde $90^{\circ} \mathrm{C}$ yükseldiği görülmektedir. PV/T panellerde panel sicaklığı maksimim $50^{\circ} \mathrm{C}$ sicaklığa yükselmektedir. PV/T-FDM kullanılan panellerde sıcaklık $40^{\circ} \mathrm{C}$ sicaklığa kadar yükselmektedir. Bu durumda panel sıcaklığından kaynaklı ortaya çıkan verim düşümü en az PV/T-FDM kullanılan panellerde gerçekleşmektedir. İkinci olarak PV/T paneller sıcaklığın yükselmesini engellemek ve verim düşüşüne ortadan kaldırmak için ideal bir yoldur.

Deneysel çalışmamızda PV/T kullanılarak, TEJ ile elektrik üretimi sağlanmıştır (Şekil 9). Tasarlanan sistem şebekeden bağımsız çalışan bir sistemdir. Sistemde üretilen enerji depolama sisteminde depolanmakta ve sistem içinde harcama yapılmaktadır. Modül yüzeyleri arasında sıcaklık farkı oluşmaya başladığında elektrik üretimi gerçekleşmektedir. Modül yüzeyleri sıcaklık farkı arttıkça gerilim ve buna bağlı akım değerleri yükselmektedir. Güç değerleri sıcaklık farkına bağlı olarak 5W'a çıkmaktadır. Sıcaklık farkı değerlerine orantılı olarak gerilim ve akım değerleri yukarı ve aşağı yönlü değişim göstermektedir. Kaynak olarak kullanılan atık ısının sürekli olarak istenilen değerlerde sistemi desteklemesi ve soğutucu kaynağın sürekli olarak sabit sıcaklıkta tutulması sistem verimi açısından önemi deney verilerinde görülmüştür. Sistem sıcaklık farkı sabit tutulamaması durumunda gerilim dalgalanması yaşanmaktadır. Anlık değişimleri azaltmak adına sıcaklık farkının korunarak yüzey sıcaklıklarını dengede tutmak; hem kaynak, hem de kuyu kabul edilen atmosfere iyi bir 1sı transferi ile mümkün olacaktır.

Tablo 3'de görüldüğ̈̈ gibi deneyler esnasında PV/T den gelen TEJ besleme suyu sıcaklığı ve TEJ çıkış suyu sıcaklıkları ölçülmüştür. TEJ 1 ile TEJ 2 için sıcak ve soğuk yüzey sıcaklıkları ölçülmüş olup, sıcaklık farkı değerleri Şekil 13'te verilmiştir. Sıcaklık farkı nedeniyle oluşan gerilim değerleri SCN 100 ile kaydedilerek Tablo 3 ve Tablo 4 'te verilmiştir. Kanatçık sıcaklıkları başlangıç durumunda atmosfer sıcaklığına sahip bulunmaktadır. Su sirkilasyonu başlamasıyla birlikte yüzey ve kanatçık sıcaklıkları artış göstermektedir.

Tablo 3: PV/T-TEJ Ölçüm Değerleri

\begin{tabular}{cccccccccc}
\hline $\begin{array}{c}\text { Ölçüm } \\
\text { No }\end{array}$ & $\begin{array}{c}\text { Giriş } \\
\text { Suyu } \\
\left({ }^{\circ} \mathrm{C}\right)\end{array}$ & $\begin{array}{c}\text { Çkış } \\
\text { Suyu } \\
\left({ }^{\circ} \mathrm{C}\right)\end{array}$ & $\begin{array}{c}\text { TEJ 1 } \\
\text { Yüzey } \\
\left({ }^{\circ} \mathrm{C}\right)\end{array}$ & $\begin{array}{c}\text { TEJ 1 } \\
\text { Kanatçlk } \\
\left({ }^{\circ} \mathrm{C}\right)\end{array}$ & $\begin{array}{c}\text { TEJ 2 } \\
\text { Yüzey } \\
\left({ }^{\circ} \mathrm{C}\right)\end{array}$ & $\begin{array}{c}\text { TEJ 2 } \\
\text { Kanatçlk } \\
\left({ }^{\circ} \mathrm{C}\right)\end{array}$ & $\begin{array}{c}\text { Ortam sıcaklı̆̆l } \\
\left({ }^{\circ} \mathrm{C}\right)\end{array}$ & $\begin{array}{c}\text { TEJ 1 } \\
\text { (Doğal) } \\
\text { Gerilimi } \\
(\mathrm{V})\end{array}$ & $\begin{array}{c}\text { TEJ 2 } \\
\text { (Cebri) } \\
\text { Gerilimi } \\
(\mathrm{V})\end{array}$ \\
\hline 1 & 28 & 27 & 27 & 25 & 27 & 25 & 25 & 0.27 & 0.45 \\
\hline 2 & 30 & 28 & 29 & 26 & 29 & 25 & 25 & 0.49 & 0.83 \\
\hline 3 & 31 & 29 & 30 & 27 & 30 & 25 & 25 & 0.76 & 1.15 \\
\hline 4 & 33 & 31 & 32 & 29 & 32 & 26 & 25 & 0.95 & 1.25 \\
\hline 5 & 37 & 35 & 35 & 31 & 35 & 26 & 25 & 1.53 & 1.85 \\
\hline 6 & 40 & 37 & 38 & 34 & 38 & 26 & 25 & 1.84 & 2.45 \\
\hline 7 & 42 & 38 & 40 & 35 & 40 & 26 & 25 & 1.95 & 2.69 \\
\hline 8 & 44 & 41 & 42 & 37 & 42 & 27 & 25 & 1.98 & 2.85 \\
\hline 9 & 44 & 42 & 42 & 36 & 42 & 27 & 25 & 2.06 & 2.95 \\
\hline 10 & 45 & 43 & 42 & 36 & 42 & 27 & 25 & 2.12 & 3.02 \\
\hline 11 & 46 & 43 & 43 & 37 & 43 & 27 & 25 & 2.18 & 3.07 \\
\hline 12 & 47 & 44 & 44 & 38 & 44 & 28 & 25 & 2.25 & 3.14 \\
\hline 13 & 48 & 45 & 44 & 38 & 44 & 28 & 25 & 2.31 & 3.17 \\
\hline 14 & 49 & 46 & 45 & 38 & 45 & 28 & 25 & 2.36 & 3.24 \\
\hline 15 & 49 & 46 & 45 & 38 & 45 & 28 & 25 & 2.37 & 3.25 \\
\hline
\end{tabular}

Deneylerde ortam sıcaklığ $125^{\circ} \mathrm{C}$ olarak ölçülmüştür. TEJ 1 ve TEJ 2 için PV/T atık 1sı giriş sıcaklığ (Tablo 3)’te verilmiştir. Giriş sıcaklıkları 33 ile $49^{\circ} \mathrm{C}$ arasında değişmektedir. TEJ giriş suyu sıcaklığ 1 yükselmesiyle birlikte modül 
yüzey sıcaklıklarında artış görülmektedir. Yüzeyler arasında sıcaklık farkı oluşmasıyla birlikte gerilim değerleri okunmaya başlanılmıştır. Yüzeyler arasında sıcaklık farkı arttıkça ölçülen gerilim değerleri artış göstermektedir (Şekil 13). Tabi dolaşımlı soğutma sisteminde sistem çalışması esnasında 1sı çekilen yüzey sıcaklığı tabii dalaşımın yetersiz kalması nedeniyle artış göstermektedir. Cebri dolaşımlı sistemde soğutma yüzeyinde sıcaklık artışı $1-3^{\circ} \mathrm{C}$ arasında gerçekleşmiştir. $\mathrm{Bu}$ nedenle cebri dolaşımlı sistemde yüzeyler arası sıcaklık farkı fazladır. Sıcaklık farkının artışı nedeniyle ölçülen gerilim değerlerinde artış görülmektedir.

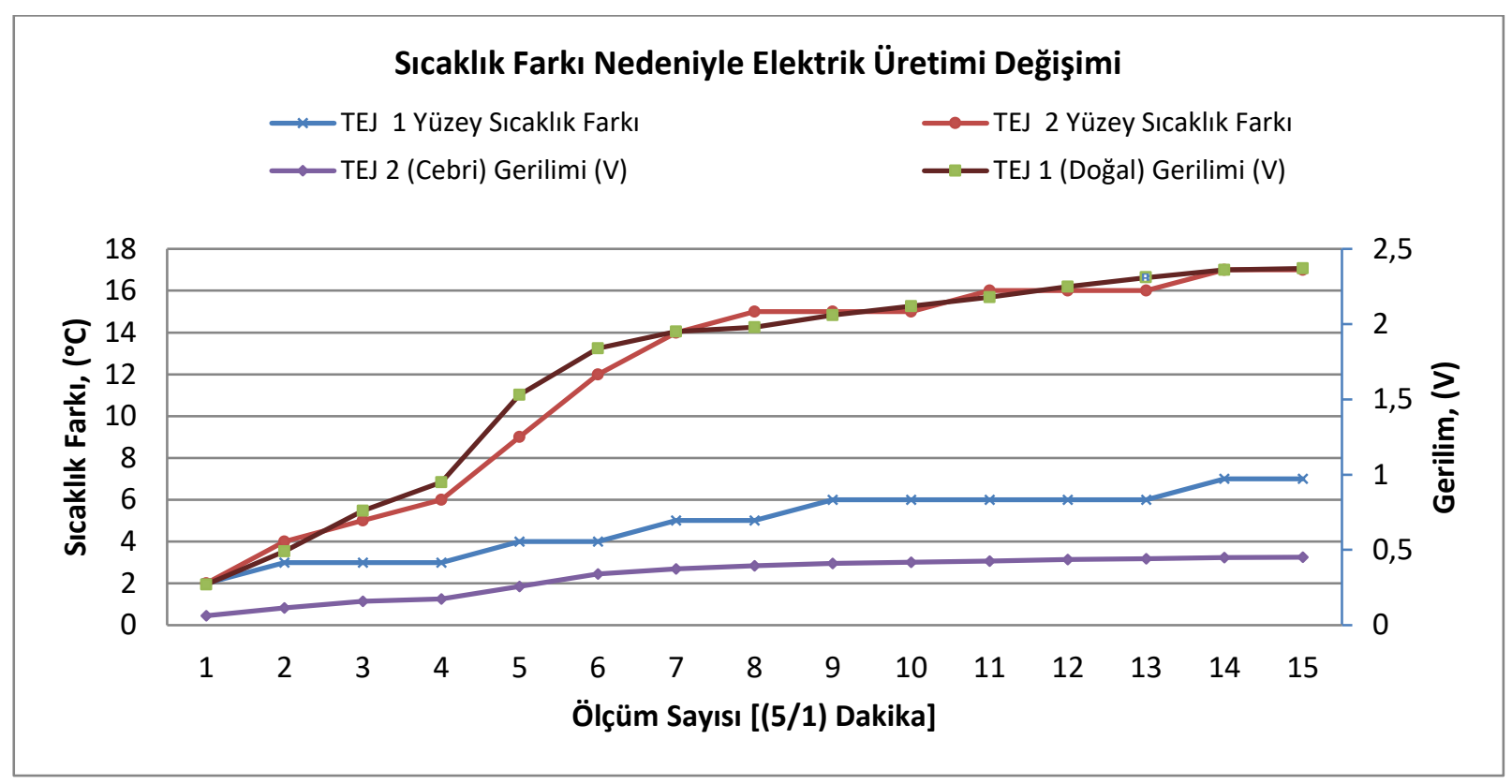

Şekil 13: Deney 1 TEJ Sicaklık Farkı Elektrik üretimi

$\mathrm{PV} / \mathrm{T}$ 'de 1sı taşıyıcı olarak kullanılan su sıcaklığı, sirkülasyon olması nedeniyle $49^{\circ} \mathrm{C}$ üzerine çıkmamıştır. $49^{\circ} \mathrm{C}$ üzerindeki sıcaklıklarda TEJ davranışının ve veriminin hesaplanabilmesi için Tablo 4 'te verilen (46-89) ${ }^{\circ} \mathrm{C}$ giriş sıcaklıklarında deneyler tekrar edilmiştir. Yapılan ölçümlerde sıcaklık farkı artmasıyla birlikte yüzey sıcaklıkları arasındaki farkın arttığı görülmüştür. Bu nedenle üretilen enerji miktarında artış gözlemlenmiştir. Cebri soğutmanın yapıldığı TEJ 2'de 1sı çekilen yüzeyin sıcaklığı fazla yükselmemesi nedeniyle ölçülen gerilim değeri tabii soğutmaya göre yüksek olmuştur. Deneylerin yüksek sıcaklıklarda yapılması mümkündür fakat PV/T'de bu sıcaklıkları görmek mümkün değildir.

Tablo 4: PV/T-TEJ Ölçüm Dĕgerleri

\begin{tabular}{cccccccccc}
\hline $\begin{array}{c}\text { Ölçüm } \\
\text { No }\end{array}$ & $\begin{array}{c}\text { Giriş } \\
\text { Suyu } \\
\left({ }^{\circ} \mathrm{C}\right)\end{array}$ & $\begin{array}{c}\text { Çıkış } \\
\text { Suyu } \\
\left({ }^{\circ} \mathrm{C}\right)\end{array}$ & $\begin{array}{c}\text { TEJ 1 } \\
\text { Yüzey } \\
\left({ }^{\circ} \mathrm{C}\right)\end{array}$ & $\begin{array}{c}\text { TEJ 1 } \\
\text { Kanatçlk } \\
\left({ }^{\circ} \mathrm{C}\right)\end{array}$ & $\begin{array}{c}\text { TEJ 2 } \\
\text { Yüzey } \\
\left({ }^{\circ} \mathrm{C}\right)\end{array}$ & $\begin{array}{c}\text { TEJ 2 } \\
\text { Kanatçlk } \\
\left({ }^{\circ} \mathrm{C}\right)\end{array}$ & $\begin{array}{c}\text { Ortam } \\
\text { sicaklığl } \\
\left({ }^{\circ} \mathrm{C}\right)\end{array}$ & $\begin{array}{c}\text { TEJ 1 } \\
\text { (Doğal) } \\
\text { Gerilimi } \\
(\mathrm{V})\end{array}$ & $\begin{array}{c}\text { TEJ 2 } \\
\text { (Cebri) } \\
\text { Gerilimi } \\
(\mathrm{V})\end{array}$ \\
\hline 1 & 46 & 44 & 43 & 28 & 43 & 26 & 25 & 1.98 & 2.48 \\
\hline 2 & 47 & 45 & 44 & 29 & 44 & 27 & 25 & 2.48 & 3.61 \\
\hline 3 & 49 & 46 & 45 & 30 & 45 & 27 & 25 & 2.52 & 3.83 \\
\hline 4 & 55 & 51 & 49 & 33 & 49 & 27 & 25 & 2.55 & 3.96 \\
\hline 5 & 59 & 55 & 52 & 35 & 52 & 27 & 25 & 2.60 & 4.02 \\
\hline 6 & 63 & 59 & 58 & 41 & 58 & 27 & 25 & 2.73 & 4.55 \\
\hline 7 & 67 & 64 & 60 & 42 & 60 & 27 & 25 & 2.89 & 5.20 \\
\hline 8 & 71 & 68 & 64 & 45 & 64 & 28 & 25 & 3.01 & 5.65 \\
\hline 9 & 75 & 71 & 67 & 47 & 67 & 28 & 25 & 3.07 & 6.05 \\
\hline 10 & 78 & 74 & 70 & 49 & 70 & 28 & 25 & 3.14 & 6.37 \\
\hline 11 & 81 & 77 & 72 & 50 & 72 & 28 & 25 & 3.25 & 6.65 \\
\hline 12 & 84 & 80 & 75 & 52 & 75 & 28 & 25 & 3.45 & 7.02 \\
\hline 13 & 87 & 82 & 77 & 53 & 77 & 29 & 25 & 3.60 & 7.40 \\
\hline 14 & 88 & 83 & 79 & 54 & 79 & 29 & 25 & 3.70 & 7.60 \\
\hline 15 & 89 & 84 & 80 & 54 & 80 & 29 & 25 & 3.87 & 7.80 \\
\hline
\end{tabular}

PV/T-FDM araştırmasında ölçülen sıcaklık değerleri TEJ'in çalışmasına elverişli olduğu gözlemlenmiştir. Sıcaklık farkına bağlı, orantılı olarak gerilim-akım değerlerinde yukarı ve aşağı yönlü değişim göstermektedir (Şekil 14). TEJ'ler için soğutma sisteminin enerji harcamadan doğal yollarla yapılması önemli bir husustur. Fakat cebri soğuma yapılması halinde sıcaklık farkı değerleri artış gösterdiği için verim artmaktadır. TEJ'ler \%3 ile \%5 veriminde çalıştıkları için doğal yollarla veya ekonomik olarak cebri soğutmanın sağlanması yararlı olacaktır. 


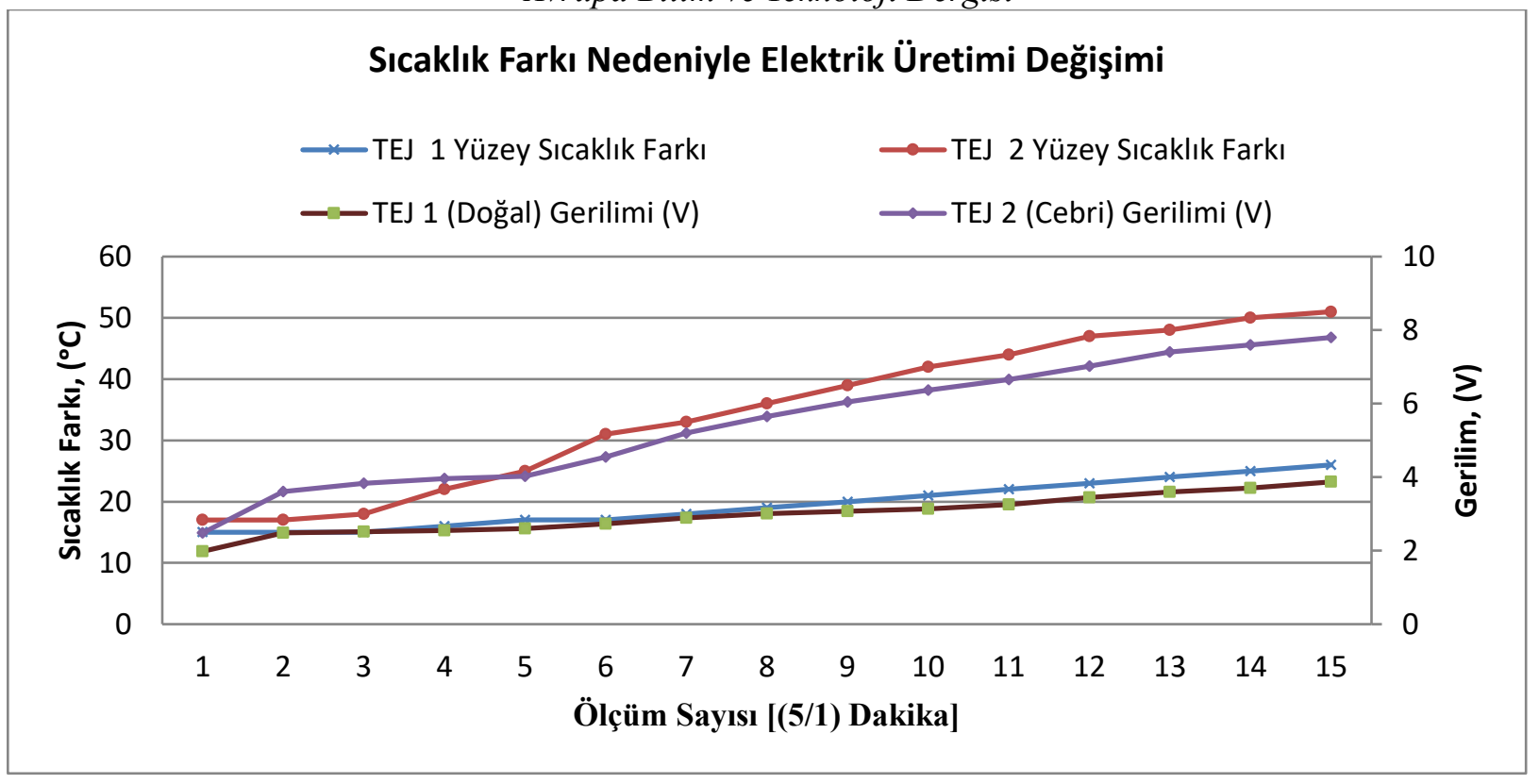

Şekil 14: Deney 2 TEJ Sıcaklık Farkı Elektrik üretimi

TE jeneratörler jeotermal enerji ile çalışabildikleri gibi motor bloklarındaki atık 1sı, egzoz gazı atık 1sısı, soba ve kazan yüzeyleri 1SıS1, merkezi ve bireysel 1sıtma sistemleri suyu 1sısı ile çalışabilmektedir. Jeotermal enerji uygulamalarında oluşan atık 1sı, motor bloklarında oluşan atık 1sı ayrıca kimyasal süreçlerde oluşan atık 1Sı TEJ'ler ile enerji üretimi ve geri kazanımında değerlendirilmesi gereken bir konudur. Jeotermal enerjinin yenilenebilir enerji kaynağı olması nedeniyle, kullanım sonrası $50^{\circ} \mathrm{C}$ sıcaklığa sahip ise TEJ ile bu kaynağı değerlendirmek en avantajlı yollardan biri olur. Güneş enerjisinin odaklaması şeklinde yapılan uygulamalarda elde edilen 1sı enerjisi modüllerin sıcak yüzeyi için kullanılabilir kaynaklardandır. Soğuk yüzeyler için şebeke suyu ile soğutma, hava ile soğutma ve cebri soğutmalar kullanılabilir. Yapılan çalışmalara bakıldığında düşük verime sahip TEJ'lerin atık 1sıdan veya doğal kaynaklardan faydalanmak suretiyle ve teknolojik gelişmelere bağlı olarak gelecekte kullanımının daha yaygın hale geleceği beklenilmektedir.

TEJ'lerin verimli olarak çalışabilmesi için yüzeyler arasında sıcaklık farkının oluşturulması gerekmektedir. Yüksek sıcaklığa sahip yüzeyin oluşturulması önemli olmakla birlikte düşük sıcaklığa sahip yüzeyin oluşturulması önemlidir. Düşük yüzey sıcaklığının oluşturulabilmesi için; bu yüzeyden 1sı çekmek enerji harcamadan yapılması yararlı olacaktır. Doğal yolla yapılan atmosferik soğutma sıcaklık farkının azalmaması koşuluyla yararlıdır. Bunun için enerji ve ekserji analizleri yapılarak yüzey şekilleri belirlenip optimum yüzey alanı hesapları yapılmalıdır. Cebri soğutma uygulamalarında sıcaklık farkı değerlerinin istenilen aralıklarda tutulması mümkün olmakla birlikte, sistem büyüklüğüne göre verimlilik ve amortisman süreleri cazip hale getirilmelidir.

\section{Sonuç}

Termoelektrik modül kullanarak imal edilmiş olan TEJ'ler elektrik üretmek amacıyla kullanılabilmektedir. TEJ'lerden elektrik üretmek için kullanılacak enerji kaynağı ekonomik olmak zorundadır. TEJ'lerde elektrik enerjisi üretmek amacıyla ekonomik olmayan enerji kaynakları kullanılırsa sistem ekonomikliğini kaybetmektedir. Bu nedenle TEJ'lerde elektrik enerjisi üretmek için atık 1sılar ve yenilenebilir enerji kaynakları tercih edilmelidir. Atık ssıları kullanarak elde edilecek güç sistem verimini arttırmakla birlikte çevreye bırakılan atık 1sıyı yararlı işe dönüştürmektedir. Yenilenebilir nerji kaynakları kullanılarak çalıştırılan TEJ'ler, kullanılan kaynağın ekonomik olması nedeniyle tercih edilmektedir. Termoelektrik modül verimlerinin artmaya devam ettiği günümüzde TEJ'ler diğer enerji kaynaklarını kaynak olarak kullanarak ekonomik elektrik üretimi yapabileceklerdir.

TEJ'lerde sistem veriminin artması için, 1S1 verilen yüzey ile 1sı çekilen yüzelerde 1sıtma ve soğutma işleminin iyileştirilmesi gerekmektedir. Termoelektrik modüllerin yüzey alanı küçük olması nedeniyle yüzeye 1sı vermek ve yüzeyden 1sı çekmek için optimizasyon çalışmaları yapılmalıdır. Sıcaklık farkının artması TEJ veriminin artması anlamına gelir. Bu nedenle kaynak ekonomik olmakla birlikte 1sı transferinin verimli bir şekilde gerçekleştirilmesi önem arz etmektedir. Son yıllarda PV hücrelerde görülen verim artışı, TEM ve TEJ'lerde görülebilmesi halinde, bağımsız ve hibrit elektrik üretim uygulamalarında daha fazla yaygınlaşacağı düşünülmektedir.

\section{Teșekkür}

Bu araştırma Karabük Üniversitesi, Bilimsel Araştırma Projeleri Koordinasyon Birimi tarafindan KABÜBAP-17-DR-435 no'lu Doktora projesi kapsamında desteklenmiştir. Desteklerinden dolayı Karabük Üniversitesi, Bilimsel Araştırma Projeleri Koordinasyon Birimine teşekkür ederiz.

\section{Semboller}




$\begin{array}{ll}\mathrm{CO}_{2} & : \text { Karbondioksit } \\ \mathrm{Kth} & : \text { Termal İletkenlik } \\ \mathrm{I} & : \text { Akım } \\ \mathrm{Mopt} & : \text { Optimal Verim } \\ \eta & : \text { Verim } \\ \mathrm{P} & : \text { Güç } \\ \mathrm{R} & : \text { Elektrik direnci } \\ \mathrm{R}_{\mathrm{L}} & : \text { Yük Direnci } \\ \mathrm{V} & : \text { Gerilim } \\ \mathrm{TC} & : \text { TEJ'in soğuk taraf sıcaklığı } \\ \mathrm{TH} & : \text { TEJ'in sıcak taraf 1Sısı } \\ \mathrm{Z} & : \text { Kalite Faktörü } \\ \Delta \mathrm{T} & : \text { Yüzeyler arasındaki sıcaklık farkı }\end{array}$

\section{Kisaktmalar}

$\begin{array}{ll}\text { EMK } & : \text { Elektro Motor Kuvvet } \\ \text { DC } & : \text { Doğru Akım } \\ \text { FDM } & : \text { Faz Değiştiren Madde } \\ \text { PCM } & : \text { Phase Change Material } \\ \text { PV } & : \text { Fotovoltaik } \\ \text { PV/T } & : \text { Fotovoltaik/Termal } \\ \text { PV/TEJ } & : \text { Fotovoltaik/Termoelektrik Jeneratör } \\ \text { PV/T/FDM } & : \text { Fotovoltaik/Termal/Faz Değiştiren Madde } \\ \text { TEJ } & : \text { Termoelektrik Jeneratör } \\ \text { TEM } & : \text { Termoelektrik Modül }\end{array}$

\section{Kaynakça}

[1] Mert, M.S., Sert, M., Mert, H.H., 2018. Isıl Enerji Depolama Sistemleri İçin Organik Faz Değiştiren Maddelerin Mevcut Durumu Üzerine Bir İnceleme, Journal of Engineering Sciences and Design, 6(1), 161-174.

[2] T.C. Enerji ve Tabii Kaynaklar Bakanlığı. "Dünya ve Türkiye Enerji ve Tabii Kaynaklar Görünümü Raporu". https://www.enerji.gov.tr/Resources/Sites/1/Pages/Sayi_15/mobile/index.html\#p=2 (05.04.2018).

[3] Energy Efficiency 2018. "Market Report Series Energy". https://webstore.iea.org/market-report-series-energy-efficiency2018 (05.04.2018).

[4] Türkiye Enerji İletim Anonim Şirketi. "Enerji Raporu”. https://www.teias.gov.tr (05.04.2018).

[5] Külcü, R., Cihanalp, C., Süslü, A., Yılmaz, D. 2016. Adana'da Global Aylık Ortalama Günlük Güneş Işınımının Modellenmesi, Süleyman Demirel Üniversitesi, Isparta.

[6] Koç, A., Yağlı H., Koç Y., Uğurlu İ., 2018. Dünyada ve Türkiye'de Enerji Görünümünün Genel Değerlendirilmesi, Mühendis ve Makine, Derleme, 59(692), 86-114.

[7] Çiçek, O, Karatay, S. (2018). Küçük \& Orta Ölçekli Fotovoltaik (PV) Modül Üretimi için Dijital PID Sıcaklık Denetimli Laminatör Deney Kiti Tasarımı ve Üretimi. Gazi Üniversitesi Fen Bilimleri Dergisi Part C: Tasarım ve Teknoloji, 6 (4), 814 823.

[8] Bahaidarah H, Subhan A, Gandhidasan P, Rehman S., 2013. "Performance Evaluation of a PV (Photovoltaic) Module By Back Surface Water Cooling For Hot Climatic Conditions”, Energy, 59, 445-453.

[9] Bjork R, Nielsan KK. 2015. "The Performance of a Combined Solar Photovoltaic (PV) and Thermoelectric Generator (TEG) System Nielsen”, Solar Energy, 120, 187-194.

[10] Gedik E., 2016. "Experimental Investigation of Module Temperature Effect on Photovoltaic Panels Efficiency", Journal of Polytechnic, 19, 569-576.

[11]TMMOB Elektrik Mühendisleri Odası "Güneş Enerji Santrallerinde Kayılar". http://www.emo.org.tr/ekler/38f0038bf09a40b_ek.pdf (05.06.2018).

[12] Konuklu Y., 2008. Mikrokapsüllenmiş Faz Değiştiren Maddelerde Termal Enerji Depolama İle Binalarda Enerji Tasarrufu, Doktora Tezi, Çukurova Üniversitesi, Adana Türkiye. 


\section{Avrupa Bilim ve Teknoloji Dergisi}

[13] Verma, P., V., Singal, S. 2008. Review of mathematical modeling on latent heat thermal energy storage systems using phasechange material. Renewable and Sustainable Energy Reviews, 12(4), 999-1031.

[14] Mohamed, S. A., Al-Sulaiman, F. A., Ibrahim, N. I., Zahir, M. H., Al-Ahmed, A., Saidur, R., Yılbaş, B.S., Sahin, A., 2017. A review on current status and challenges of inorganic phase change materials for thermal energy storage systems. Renewable and Sustainable Energy Reviews, 70, 1072-1089.

[15] Kylili, A., Fokaides, P. A., 2016. Life Cycle Assessment (LCA) of Phase Change Materials (PCMs) for building applications: A review. Journal of Building Engineering, 6, 133-143.

[16]Zhao, C., Zhang, G., 2011. Review on microencapsulated phase change materials (MEPCMs): Fabrication, characterization and applications. Renewable and Sustainable Energy Reviews, 15(8), 3813-3832.

[17] Su, W., Darkwa, J., Kokogiannakis, G., 2015. Review of solid-liquid phase change materials and their encapsulation technologies. Renewable and Sustainable Energy Reviews, 48, 373-391.

[18] Eslamnezhad, H. and Rahimi, A.B., 2017. "Enhance heat transfer for phase-change materials in triplex tube heat exchanger with selected arrangements of fins", Applied Thermal Engineering, 113: 813-821.

[19] Doğdu MF., Şişman A. 2013. Termoelektrik Soğutucuların Performansına Doğrudan Temaslı Isı Değiştiricilerin Etkilerinin Deneysel İncelenmesi, Yüksek Lisans Tezi, İstanbul Teknik Üniversitesi, İstanbul, Türkiye.

[20] Kwan TH, Wu X. 2016. "Power and Mass Optimization Of The Hybrid Solar Panel And Thermoelectric Generators", Applied Energy, 165, 297-307.

[21] Özkaymak M, Baș Ş, Acar B, Yavuz C, 2014. "Atık Baca Gazı Kullanımı ile Termoelektirik Jeneratörlerde Elektrik Üretiminin Faydalı kullanımının Deneysel İncelenmesi”, Gazi Üniversitesi Fen Bilimleri Dergisi, Part:C, Tasarım Ve Teknoloji, Part C, 2(4), 289-298.

[22] Kunt MA., 2014. “İçten Yanmalı Motor Atık Isılarının Geri Kazanımında Termoelektrik Jeneratörlerin Kullanımı”, ElCezerî Fen ve Mühendislik Dergisi, 3,2, 192-203.

[23] Brovne MC, Norton B, Cormack SJ. 2016. "Heat Retention Of A Photovoltaic/Thermal Collector With PCM", Solar Energy $33,533-548$.

[24] Ahıska R., 2000.“Termoelektrik Modülün Dinamik Çıkış Parametrelerinin Araştırması İçin Yeni Bir Yöntem”, Gazi Üniversitesi. Mühendislik Mimarlık Fakültesi Dergisi, 22-4, 709-716 